\title{
Impact of Foreign Fund Flows on Volatile Indian Stock Market
}

\author{
Monojit Dutta $^{1}$ and Amalendu Bhunia ${ }^{2}$ \\ ${ }^{1}$ Assistant Professor, St Xavier's University, Kolkata, West Bengal, India \\ ${ }^{1}$ Research Scholar, ${ }^{2}$ Professor \\ ${ }^{1 \& 2}$ Department of Commerce, University of Kalyani, West Bengal, India \\ E-mail: monojitdutta68@gmail.com, bhunia.amalendu@gmail.com
}

\begin{abstract}
This study examines the impact of foreign funds flows in terms of FDI and FPI on Indian stock market. Foreign fund flows in and out of Indian stock markets are now an ample portion of the market activity because FDI influences the growth directly and FPIs investment affects the growth indirectly by improving equity market performance of the host country. This study is based on yearly time series data for the period from 1992-93 to 2019-20. While analysing the data, descriptive statistics, correlation analysis, ADF unit root test, co integration and Wald test have been used. There is a positive relationship of FDI and FPI with Sensex. The volatility of Sensex is influenced by prior volatility and foreign fund flows. The Johansen co integration test results indicate that all the variables have a long-run relationship of the same order. The Wald test results confirm that there is a significant shortrun causal relationship of FDI and FPI with Indian stock market. These findings suggest that volatility of Indian stock market and foreign flows have increased over the period of study.

Keywords: Foreign Fund Flows, Sensex, India, Correlation Analysis, Cointegration Test
\end{abstract}

\section{INTRODUCTION}

The international capital flows have huge potential for the economies to grow all around the world. The developing countries are able to reap the benefits of foreign capital flows in the best possible ways. The monetary policy of the home country gives the freedom to the foreign investors to invest their money as per their liking. International capital flows have increased dramatically after the liberalization (Kurtishi-Kastrati, 2013). During the 1990s gross capital flows between industrial countries rose by 300 percent, while trade flows increased by 63 percent (Sethi and Patnaik, 2004). Much of the increase in capital flows is due to trade in equity and debt markets, with the result that the international pattern of asset ownership (Narsale, 2016).

The investment of capital that flows from one country to another country is known as foreign investment. The inflow of foreign investment is normally encouraged in developing nations because it complements and stimulates domestic investment in capital-scarce economies. In India, foreign investments were allowed in 1991 either through stock market investment in listed companies referred to as Foreign Portfolio Investors investment or directly in listed and unlisted companies referred to as Foreign Direct Investment (Joo and Mir, 2014). Among two former play a dynamic role in shaping the stock market indices and stock prices of various companies in the host country. FDI is considered as a developmental tool and helps in achieving self-reliance in various sectors, thereby leads to the overall development of the economy (Bhusan \& Mittal, 2015). However, FDI affects the growth directly through capital formation, strengthening infrastructure, increasing productivity, and generating employment opportunities while as FPIs investment affects the growth indirectly by improving equity market performance of the host country and also tells upon their corporate governance issues.

FPIs capital flows are often viewed as a double-edged sword (Javaid, 2016). On the one hand, in emerging economies that undergoing the phase of liberalization FPIs investment improves market efficiency and leads to a decline in the cost of capital. On the other hand, it is argued by the policymakers and researchers, that FPI's trades exacerbate volatility in the stock markets of the host country (Ogbonna et al., 2016).

Stock markets are known to be an important source of capital for corporate firms. They help to make a meeting point between buyers and sellers of long-term funds. For emerging economies, the challenge of low savings and investment culture further negatively impacts the ability of the stock market to mop up domestic funds for fund users (Patnaik and Pandey, 2019). This had heightened the need for the capital market in developing countries to open up foreign investors to invest. International financial institutions have advocated for developing countries to liberalize their capital account over the years in other to foster both free entry and exit of capital. Some developing countries accepted this policy in anticipation of the expected enormous benefits (Omorokunwa, 2018). Keeping in view of the above, this study examines the impact of foreign fund flows on the Indian stock market.

\section{LITERATURE REVIEW}

Zahirullah and Shah (2019) the researcher focused on studying the relationship between stock market indicators and net portfolio investment. The researchers found that the results demonstrate that all the stock market indicators have a positive and significant impact on NFPI except the market risk which has a negative relation with NFPI. Raghavan and Selvam (2017) suggested that though FPI has many advantages to the country however it should have a certain 
limitations that should not lead to inflation where the prices may go up. Kapoor and Sachan (2015) examined the impact of FDI and FII on the Indian Stock market and concluded that FDI doesn't have any impact on the stock market trends but FII determines the trend of the stock market in India. Karthik and Kannan (2011) in their research of the impact of FDI on the Indian stock market and also about the substituting role of FDI in the development of the Indian Stock Market founded that the volatility of the exchange rates should be minimized through proper monetary policy and results of his analysis show that these macro-economic variables have a powerful impact in the stock market development of India.

Dutta (2010) focused on the increase in the degree of multifractality prior to the anomalous behaviour in the Sensex values is also observed. The augment in the extent of association for the period from 2007 to 2009 is also accountable for the sudden rise and the disastrous plummet in the values of Sensex. Biswas (2006) the author focused on the post-liberalization growth, development, and efficiency of the Indian stock market vis-a-vis another select Asian market. It was found that trading has become increasingly concentrated in some sectors and companies, and the higher volatility in the market, without a corresponding higher return, portends greater risk and more instability for investors. Vasudevan (2006) the researcher tried to focus on the foreign institutional investor inflows released in November 2005. It was found that the spiral nature of the co-movement of inflows and stock prices warrants testing of the hypothesis surge the inflows based only on economic fundamentals or the strength of traded companies and it quietly ignores the perception that subaccounts and participatory notes provide the avenues through which some speculative flows could have occurred.

Pethe and Karnik (2000) in their paper the authors studied the inter-relationships between stock prices and important macro-economic variables. It was found that there does not seem to be any kind of long-run, stable relationship between the stock prices and the macro economy. Agarwal (1997) observed the determinants of foreign portfolio investment and its impact on the national economy in six developing Asian countries. It was found that the index of economic activities and inflation rate demonstrates an upward trend. Volatility in portfolio flows has not augmented over time. The ratio of foreign debt and debt-servicing to GDP has declined. But the rule of thumb concerning the subject of sustainability of FPI proposes that India and Indonesia have crossed the upper bounds of allowable debt ratios.

\section{DATA AND METHODOLOGY}

This study is conducted based on daily time series data collected from IndStat database. The yearly time series data of FDI, FPI and Sensex have been collected for the year from $1992-93$ to $2019-20$ with 28 observations. To analyse the data, descriptive statistics, correlation analysis, ADF unit root test, GARCH model, Johansen co integration test and Wald test have been considered.

\section{A. ADF Unit Root Test}

ADF unit root test is used to validate the stationarity of a time series data series. For this, the ADF Test has used in which a null hypothesis is assumed since the survival of a unit root.

$\mathrm{H}_{0}=$ There exists a unit root

$\Delta \mathrm{y}_{\mathrm{t}}=\propto_{0}+\theta \mathrm{y}_{\mathrm{t}-1}+\sum \propto \Delta \mathrm{y}_{\mathrm{t}}+\mathrm{e}_{\mathrm{t}}$

Where $\mathrm{y}$ signifies the time series, $\mathrm{t}$ is the time period, $\mathrm{n}$ is the optimum number of lags, $\alpha_{0}$ is a constant and $e$ is the error term.

\section{B. GARCH Model}

The GARCH model has become the criterion technique for modelling volatility in financial time series data.

The GARCH $(\mathrm{p}, \mathrm{q})$ can be represented as $\sigma_{t}^{2}=\omega+\sum_{i=1}^{p} \sigma_{i} \xi^{2}+\sum_{j=1}^{q} \beta_{i} \sigma_{i-j}^{2}$

Where $\sigma_{t}^{2}$ a function of is lagged values of $\xi_{t}^{2}$ and $\omega,\left\{\sigma_{i}\right\} i . . . p$ and $\left\{\beta_{j}\right\}^{i-j} j \ldots . . q$ are positive constants. Larger $\alpha$ values represent higher sensitivity to new information, whereas larger $\beta$ values represent a higher amount of time for the change to disappear.

\section{Johansen Co Integration Test}

Johansen recommends two different likelihood ratio tests of the significance of these canonical correlations and thus the reduced rank of the $\Pi$ matrix: the trace test and maximum eigen value test.

$\mathrm{J}_{\text {trace }}=-\mathrm{T} \sum \ln \left(1-\lambda_{\mathrm{i}}\right)$

$\mathrm{J}_{\max }=-\mathrm{T} \ln \left(1-\lambda_{\mathrm{r}+1}\right)$

Here $\mathrm{T}$ is the sample size and $\lambda \mathrm{i}^{\wedge}$ is the $\mathrm{i}$ :th largest canonical correlation. The trace test tests the null hypothesis of $r$ co integrating vectors against the alternative hypothesis of $n$ co integrating vectors. The maximum eigen value test, conversely, tests the null hypothesis of $\mathrm{r}$ co integrating vectors against the alternative hypothesis of $\mathrm{r}+1$ co integrating vectors. Neither of these test statistics follows a chi square distribution in general; asymptotic critical values can be found. Since the critical values used for the maximum eigen value and trace test statistics are based on a pure unit-root assumption, they will no longer be correct when the variables in the system are near-unit-root processes. Thus, the real question is how sensitive Johansen's procedures are to deviations from the pure-unit root assumption. 


\section{EMPIRICAL ANALYSIS}

\section{A. Descriptive Statistics}

TABLE I DESCRIPTIVE STATISTICS

\begin{tabular}{|l|c|c|c|}
\hline & FDI & FPI & SENSEX \\
\hline Mean & 16901.84 & 38797.21 & 14895.62 \\
\hline Maximum & 47643.00 & 140033.0 & 41253.74 \\
\hline Minimum & 264.1000 & 13.00000 & 3055.410 \\
\hline Std. Dev. & 16820.14 & 39111.48 & 11837.84 \\
\hline Skewness & 0.584416 & 1.129364 & 0.632743 \\
\hline Kurtosis & 1.781495 & 3.317701 & 2.180346 \\
\hline Observations & 28 & 28 & 28 \\
\hline
\end{tabular}

Table I encloses the descriptive statistics of FDI, FPI, and Sensex. The standard deviation shows that there is variability among annual standard deviation among three variables. The standard deviation is highest in case of FPI, followed by FDI and SENSEX. The skewness is positive for the all the three series. The positive skewness entails that the observations are distributed on the above side of the means i.e., higher probability of attaining positive observations and vice versa.

\section{B. Correlation Analysis}

Correlation is used to study the relationship of the variables FDI, FII, and BSE Sensex. The correlation analysis shows that that there is a very strong positive correlation between FDI \& Sensex and FDI, and the correlation is found to be significant at 1 percent level of significance. When it comes to FPI it was found that there is a moderate positive correlation between FII \& Sensex and the correlation is significant at 1 percent level of significance.

TABLE II CORRELATION STATISTICS
\begin{tabular}{|l|c|c|c|}
\hline & FDI & FPI & SENSEX \\
\hline FDI & 1.00 & & \\
\hline FPI & 0.43 & 1.00 & \\
\hline SENSEX & 0.91 & 0.48 & 1.00 \\
\hline
\end{tabular}

\section{ADF Unit Root Test Results}

Stationary of time series data is a prerequisite for the use of any econometric model. Therefore, Augmented Dickey Fuller (ADF) test has been used for this purpose. The results made by the test are shown in the Table III.

TABLE III ADF UNIT ROOT TEST RESULTS

\begin{tabular}{|l|c|c|c|c|}
\hline & \multicolumn{2}{|c|}{ At Level } & \multicolumn{2}{c|}{ At 1 ${ }^{\text {st }}$ Differenced } \\
\hline & t-stat & C.V. at .05 & t-stat & C.V. at .05 \\
\hline FDI & -0.41 & -2.98 & -5.88 & -2.98 \\
\hline FPI & -1.49 & -2.98 & -10.62 & -2.98 \\
\hline SENSEX & -0.80 & -2.98 & -6.63 & -2.98 \\
\hline
\end{tabular}

The results of ADF test reveal that null hypothesis is not rejected at level because the computed ADF test statistics of FDI, FPI and Sensex is higher than critical values at a 5 per cent level of significance. The results of ADF test also disclose that null hypothesis is rejected at $1^{\text {st }}$ differenced because the computed ADF test statistics of FDI, FPI and Sensex is smaller than critical values at a 5 per cent level of significance.

Therefore, it is concluded that FDI, FPI and Sensex do not have a unit root problem at $1^{\text {st }}$ differenced but the series is non stationary at level at a 5 per cent level of significance. After the confirmation of stationary nature of data series GARCH $(1,1)$ model is used to observe the volatility of Sensex.

\section{GARCH Model Test Results}

After authentication of stationary nature of data series the estimated GARCH $(1,1)$ model is used. Table IV exhibits parameter estimates of GARCH $(1,1)$ model for SENSEX. The variance equation provides the one period forward forecast variance derived from past information, recognized as conditional variance.

The GARCH results of Sensex demonstrate that ARCH term, GARCH term, FDI and FPI is significant that designates that present volatility is persuaded by past volatility, the ARCH term is not significant which demonstrates that volatility of Sensex is not influenced by information about volatility in earlier period and foreign investment flows are influencing the volatility of Sensex. Thus, the volatility of Sensex is influenced by prior volatility and foreign flows.

TABLE IV GARCH MODEL TEST RESULTS

\begin{tabular}{|l|c|c|c|c|}
\hline & Coefficient & S.E. & $\begin{array}{c}\text { Z- } \\
\text { statistic }\end{array}$ & Probability \\
\hline$\omega$ (constant) & 2.43 & 0.84 & 1.59 & 0.12 \\
\hline $\begin{array}{l}\alpha \text { (arch } \\
\text { effect) }\end{array}$ & 0.11 & 0.05 & 0.88 & 0.56 \\
\hline $\begin{array}{l}\beta \text { (garch } \\
\text { effect) }\end{array}$ & 0.46 & 0.02 & 6.41 & 0.00 \\
\hline FDI & -0.01 & 0.00 & -3.01 & 0.00 \\
\hline FPI & -0.001 & 0.00 & 11.24 & 0.00 \\
\hline
\end{tabular}

\section{E. Johansen Co Integration Test Results}

Co integration tests help makes out any significant relationship between variables. Generally, we assume that the system is integrated of order I(1), the thought is that selected three variables are likely to be co integrated under the Johansen co integration test assumption as variables influence market performance, resulting in co integration in the long-run. 
TABLE V JOHANSEN COINTEGRATION TEST

\begin{tabular}{|c|c|c|c|c|}
\hline \multicolumn{5}{|c|}{ Unrestricted Co integration Rank Test (Trace) } \\
\hline Hypothesized & & Trace & $\mathbf{0 . 0 5}$ & \\
\hline No. of CE(s) & Eigenvalue & Statistic & Critical Value & Prob.** \\
\hline $\mathrm{r} \leq 0^{*}$ & 0.75 & 36.75 & 29.79 & 0.0013 \\
\hline $\mathrm{r} \leq 1$ & 0.68 & 10.72 & 15.49 & 0.1330 \\
\hline $\mathrm{r} \leq 2$ & 0.34 & 1.51 & 3.84 & 0.4563 \\
\hline Unrestricted Co integration Rank Test (Maximum Eigenvalue) \\
\hline Hypothesized & \multicolumn{5}{|c|}{ Max-Eigen } & $\mathbf{0 . 0 5}$ & \\
\hline No. of CE(s) & Eigenvalue & Statistic & Critical Value & Prob.** \\
\hline $\mathrm{r} \leq 0$ & 0.75 & 27.02 & 21.13 & 0.0203 \\
\hline $\mathrm{r} \leq 1$ & 0.68 & 20.21 & 14.26 & 0.1225 \\
\hline $\mathrm{r} \leq 2$ & 0.34 & 1.16 & 3.84 & 0.6313 \\
\hline \multicolumn{5}{|c|}{ Max-eigen value test indicates 1 co integrating eqn at the 0.05 level } \\
\hline \multicolumn{5}{|c|}{$*$ denotes rejection of the hypothesis at the 0.05 level } \\
\hline \multicolumn{6}{|c|}{$* *$ MacKinnon-Haug-Michelis (1999) p-values } \\
\hline
\end{tabular}

Having established that selected variables in our sample turn into stationary when first-differenced and selected a lag length of 2, we use a critical value of 5 percent in the Johansen co integration test. In addition, we use a balancing deduction method involving deterministic factors on the condition that the linear trend is assumed to be fundamentally linear and not quadratic. The co integration test results are given in Table $\mathrm{V}$, which measures two likelihood ratios: the maximum eigenvalues and trace statistics. The maximum eigenvalue and trace statistics exceed their critical value $(r \leq 0)$, with one co integrating equation, which is significant at the 5 percent level. Therefore, both test results validate the long-run relationship among the selected variables.

\section{F. Wald Test Results}

TABLE VI WALD TEST RESULTS

\begin{tabular}{|c|c|c|c|}
\hline Test Statistic & Value & df & Probability \\
\hline \multicolumn{5}{|c|}{ Sensex and FDI } \\
\hline Chi-square & 1.10 & 2 & 0.57 \\
\hline \multicolumn{4}{|c|}{ Sensex and FPI } \\
\hline Chi-square & 1.17 & 2 & 0.51 \\
\hline
\end{tabular}

Wald test is useful for identifying short-run causal relationship among three selected variables. We test the short-run association of FDI and FPI with Indian market by estimating the coefficients of the lagged difference terms and using the Wald test to determine the existence of shortrun causality. Table VI indicates that the probability of the Wald test statistic is higher than 0.05 in both cases, implying that there is no significant short-run causal relationship among the variables.

\section{CONCLUSION}

This study examines the impact foreign fund flows in terms of FDI and FPI on Indian stock market. We find a positive relationship of FDI and FPI with Indian stock market in our sample. The time series stock index values are not stationary at level but stationary at first differenced. The volatility of Sensex is influenced by prior volatility and foreign fund flows. The Johansen co integration test results indicate that all the variables have a long-run relationship of the same order. The Wald test results confirm that there is significant short-run causal relationship of FDI and FPI with Indian stock market. These findings suggest that volatility of Indian stock market and foreign flows have increased over the period of study.

\section{REFERENCES}

[1] Agarwal, R. N. (1997). Foreign portfolio investment in some developing countries: A study of determinants and macroeconomic impact. Indian Economic Review, 32(2), 217-229.

[2] Akinlo, A. (2004). Foriegn Direct Investment and Growth in Nigeria: An Empirical Investigation. Journal of Policy Modeling, 26, 627-639.

[3] Anubha, S. (2013). A Study of Influence of FII Flows on Indian Stock Market. GYANPRATHA - ACCMAN Journal of Management, 5(1).

[4] Banerjee, A., \& Sarkar, S. (2006). Modelling Daily Volatility of the Indian Stock Market Using Intra-day Data. IIM Calcutta, WPS No. 588/March.

[5] Biswas, J. (2006). Indian stock market in comparison. Economic and Political Weekly, 41(18), 1747-1752.

[6] Bhusan, A., \& Mittal, I. (2015). Role of Foreign Direct Investment in the Development of Indian Economy. RMS Journal of Management \& IT, 7(1 \& 2), 132-137.

[7] Chakrabati, R. (2001). FII Flow to India:Nature and Causes. Money and Finance, 2(7).

[8] Dutta, S. (2010). Multifractal detrended fluctuation analysis of SENSEX fluctuation in the Indian stock market. Canadian Journal of Physics, 88(8), 545-551.

[9] Javaid, W. (2016). Impact of Foreign Direct Investment on Economic Growth of Pakistan - An ARDL-ECM Approach. 
[10] Joo, B.A., \& Mir, Z.A. (2014). Impact of FIIs Investment on Volatility of Indian Stock Market: An Empirical Investigation. Journal of Business \& Economic Policy, 1(2), 106-114.

[11] Kapoor, S., \& Sachan, R. (2015). Impact of FDI \& FII on Indian Stock Markets. International Journal of Research in Finance \& Marketing, 5(4), 9-17.

[12] Karthik, R., \& Kannan, N. (2011). Impact of Foreign Direct Investment on Stock Market Development: A Study with reference to India. International Journal of Management, 2(2), 75-92.

[13] Kurtishi-Kastrati, S. (2013). The Effects of Foreign Direct Investments for Host Country's Economy. 5(1), 29-38.

[14] Ogbonna, O., Odo, S., Stephen, I., \& Anoke, C. I. (2016). Foreign Portfolio Investment and Stock Market Growth in Nigeria. Developing Country Studies, 6(11), 64-76.

[15] Omorokunwa, O. G. (2018). Stock Market Performance and Foreign Capital Flow. Amity Journal of Finance, 3(2), 24-41.

[16] Pal, P. (2004). Foriegn Institutional Investment in India. Research on Indian Stock Market Volatility, 12
[17] Pal, P. (2005). Recent Volatility in Stock Market in India and Foreign Instituttional Investors. Economic and Political Weekly.

[18] Patnaik, I., \& Pandey, R. (2019). Savings and capital formation in India. National Institute of Public Finance and Policy Working paper 271, 1-43.

[19] Pethe, A., \& Karnik, A. (2000). Do indian stock markets matter? Stock market indices and macro-economic variables. Economic and Political Weekly, 35(5), 349-356.

[20] Raghavan, S., \& Selvam, M. (2017). Determinants of Foreign Portfolio Investment and their effects on the Indian Stock Market International Journal of Management (IJM), 8(3), 105-115.

[21] Vasudevan, A. (2006). A note on portfolio flows into India. Economic and Political Weekly, 41(2), 90-92.

[22] Zahirullah, Z., \& Shah, M. H. (2018). Equity market indicators as drivers of foreign portfolio investment in Pakistan. Asia Proceedings of Social Sciences, 2(2), 43-47. 